\title{
Landscape Planning and Design for Natural Disaster Mitigation and Response from a design simulation of the Bluestone Dam failure
}

Ayaka H. Matthews

West Virginia University

Follow this and additional works at: https://researchrepository.wvu.edu/etd

\section{Recommended Citation}

Matthews, Ayaka H., "Landscape Planning and Design for Natural Disaster Mitigation and Response from a design simulation of the Bluestone Dam failure" (2013). Graduate Theses, Dissertations, and Problem Reports. 3395.

https://researchrepository.wvu.edu/etd/3395

This Thesis is protected by copyright and/or related rights. It has been brought to you by the The Research Repository @ WVU with permission from the rights-holder(s). You are free to use this Thesis in any way that is permitted by the copyright and related rights legislation that applies to your use. For other uses you must obtain permission from the rights-holder(s) directly, unless additional rights are indicated by a Creative Commons license in the record and/ or on the work itself. This Thesis has been accepted for inclusion in WVU Graduate Theses, Dissertations, and Problem Reports collection by an authorized administrator of The Research Repository @ WVU. For more information, please contact researchrepository@mail.wvu.edu. 
Landscape Planning and Design for

Natural Disaster Mitigation and Response

from a design simulation of the Bluestone Dam failure

Ayaka H. Matthews

Thesis / Dissertation submitted to the Davis college of Agriculture, Natural Resources \& Design at West Virginia University in partial fulfillment of the requirements for the degree of

\author{
Master of Landscape Architecture \\ in \\ Landscape Architecture / Environmental Design
}

Charles B. Yuill, MLA., Chair

Angela S. Campbell, MLA. Ron Dulaney Jr., M. Arch.

Department of Landscape Architecture / Environmental Design Morgantown, West Virginia 2013

Keywords: Disaster Management ; Flood Management ; River Design ; Low Impact Development ; Green Infrastructure ; Climate Change Copyright 2013 Ayaka H. Matthews 


\title{
ABSTRACT \\ Landscape Planning and Design for Natural Disaster Mitigation and Response from a design simulation of the Bluestone Dam failure
}

\author{
Ayaka H. Matthews
}

The frequency and the intensity of natural disasters, especially weather-related disasters such as storms or floods, have been increasing rapidly in the last 20 years. This trend is expected to continue to increase in the future due to climate change. Among natural hazards, floods are the most serious type, causing more cost and loss of life than any other natural hazard in the world. In addition, there are 27,000 dams, which is equal to $32 \%$ of all dams in the country, that have the potential to be damaged or fail. This could cause catastrophic damages in communities that exist downstream from those dams.

In the United States, disaster management has been addressed by new policies in government and new engineering techniques. However, their methods have not been successful in regards to flood management. They have not focused on coexisting with river dynamics, but controlling it to protect more properties for development along the river. The fundamental principle of landscape architecture is to create balance - balance between the needs of people and the needs of the environment, between the manmade and the natural, as well as between development and conservation. From this perspective, landscape architectural methods could provide different and alternative choices for disaster management, other than that of the conventional methods.

This paper reviews one project conducted to achieve flood management planning and design from the landscape architectural perspective. The goal of this project is to propose landscape planning and designs focusing on flood management, based on a simulation of a Bluestone Dam failure. Bluestone Dam is one of many dams in West Virginia with a high hazard potential. The project is composed of two projects, one is in a community that lies upstream from the Bluestone Dam, and the other is in a community that is located downstream of the dam. The objective of the upper stream project was to mitigate the risk of failure to the dam through stormwater management planning. The objective of the downstream project was to propose planning and design to respond to the potential of a failure in the dam. The project concluded that stormwater management with Low Impact Development strategies would be a feasible and practical plan to mitigate the risk of dam failure. The project also proposed a successful plan of flexible waterfront designs which can respond to flood emergencies as well as be coexistent with local river dynamics. 


\author{
LANDSCAPE PLANNING AND DESIGN FOR \\ NATURAL DISASTER MITIGATION AND RESPONSE \\ FROM A DESIGN SIMULATION OF THE BLUESTONE DAM FAILURE \\ Ayaka H. Matthews \\ Thesis / Dissertation submitted to the \\ Davis college of Agriculture, Natural Resources \& Design \\ at West Virginia University \\ in partial fulfillment of the requirements \\ for the degree of \\ Master of Landscape Architecture \\ in \\ Landscape Architecture / Environmental Design \\ APPROVAL OF THE EXAMINING COMMITTEE
}

Charles B. Yuill, MLA., Chair

Angela S. Campbell, MLA.

Ron Dulaney Jr., M. Arch.

Date 


\section{TABLE OF CONTENTS}

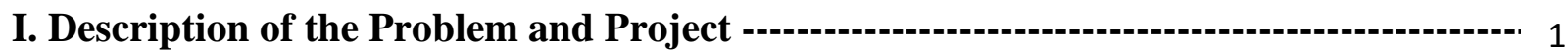

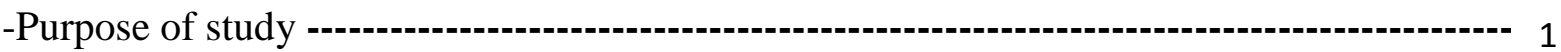

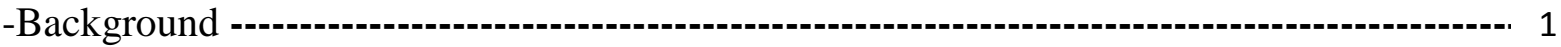

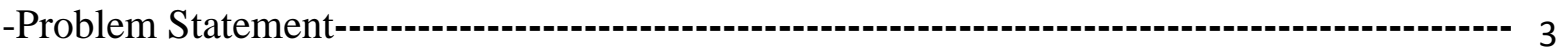

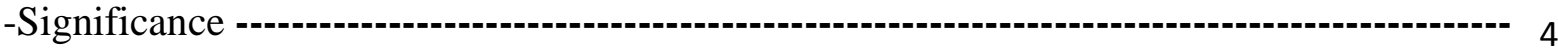

-Goals and objectives -.--- 5

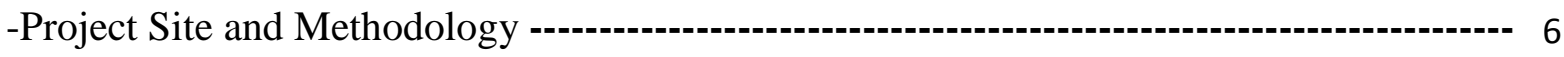

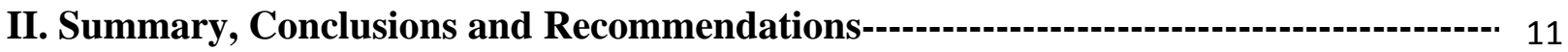

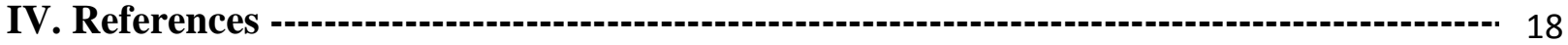




\section{Introduction}

\section{-Purpose of project}

Natural hazards have been major threats to the human world since the ancient time. Although our technology has improved enough to build tall levees to protect human capital from flooding, or even build earthquake resistant buildings, there are thousands of people dying from natural disasters every year. Moreover, the risk from natural hazards has been increasing due to environmental degradation, concentration of population in urban areas, the complication of infrastructure, and also climate change. Disaster management has been developed against these issues, but it has been mostly addressed by policy making and engineering techniques. Since landscape architecture deals with natural systems and elements to achieve sustainable development nowadays, it would be able to provide more solutions to the natural disaster issues with some different point of view than that of policies and engineering. The purpose of this project is to apply landscape architectural techniques in disaster management and propose planning and designs with disaster management for the communities. It will especially focus on mitigation and response to flood hazard to address the climate change issue for future generations. This project also will examine not only how to achieve disaster management, but also to enhance sustainability, economy and environment for the communities.

\section{-Background}

The risk of natural hazards has been increasing, and disaster management is getting more and more important nowadays. According to the analysis by the United Nations Office for Disaster Risk Reduction (UNISDR), disasters around the world have become more frequent in the last 20 years. 4.4 billion people were affected by some kind of disasters which is equal to $64 \%$ of the world's population, 2.0 trillion US dollar were lost for the damages which is similar to 25 years 
of total Overseas Development Aid, and 1.3 million people were killed which is comparable to 3,125 jumbo jets(UNISDR, The impacts of disasters since the 1992 Earth Summit). Among all the natural hazards, hydrological, meteorological or climatological events such as storms or floods, which is called weather-related disasters, have been increasing the frequency and the intensity rapidly. These type of natural hazards are equal to $76 \%$ of the total events, and caused the $45 \%$ of the total deaths and $79 \%$ of the total economic losses caused by natural hazards in the last 20 years. To make matters worse, this trend of increase is expected to be continuous to the future due to global warming. UNISDR and The IPCC Fourth Assessment Report (IPCC, 2007) has reported that climate change caused by global warming has increased extreme weather events, and it is likely to increase the number and scale of disasters. Especially, the frequency of heavy precipitation events is expected to increase mostly over the lands due to the increase of water vapor in the atmosphere by global warming (UNISDR, 2009).

Of all of the disasters floods have caused the most casualties and greatest damages to human societies. According to Jha et al(2011), the frequency of floods has radically increased from 10 in 1950 to around 200 -250 in 2010 worldwide, and the number of people affected and the amount of economic and financial loss has increased. WMO (2004) reported that178 million people were affected in 2010 and the estimated economic loss was US\$ 40billion in the peak years of 1998 and 2010 in the world. Floods are responsible for more than half of the total damage costs caused by natural hazards in the world in the last five decades. Because of the likelihood of increasing heavy precipitation due to the climate change, flood management is one of the most important activities in disaster management all over the world. 


\section{-Problem Statement}

The conventional methods for flood management in the United States have been addressed by politics and engineering, and the main ideology lies not in terms of coexistence with the river dynamics but the control of it. The Flood Control Act of 1936 (FCA, 1936) was an act of the United States Congress signed into law by President Franklin Delano Roosevelt on 22 June 1936 after the gigantic flood on the Mississippi in 1927 (Arnold,1988). Arnold (1988) pointed out that using the term "flood control" instead of "flood damage reduction" as the goal of the federal government represents that there is a more optimistic human, institutional, and political response to the issues including floods, engineering. It focused on protecting and creating more lands for economic development along the river by using structural measures. Under the Act, major civil engineering projects such as dams, levees, dikes, and other flood control measures were authorized through the United States Army Corps of Engineers and other Federal agencies. 383 major lake and reservoir projects were operated by the Corps so far, which resulted in building over 8,500 miles of levees and dikes, developing about 90 major shoreline protection projects along 240 miles of the nation's 2,700 miles of shoreline (U.S. ARMY, n.d.). In spite of these efforts, an evaluation of this program after 20 years of experience concluded that flood damages continued to increase nationally. Sheaffer et al (2002) suggested that one of the reasons for the increase is that these methods resulted in causing more intensive development in the protected area by flood control structures, but rare flood events like more than 100 years flood events could exceed or destroy the structures and cause more catastrophic damages. Another reason for the increase in flood damages was that development continued in floodplain areas, which were not protected by flood control structures. These flood control methods also have resulted in losing floodplains, which are one of the most valuable ecosystems throughout the nation 
(NWF,2013). Moreover, not only the construction cost, but also the maintenance cost of these

flood control structures will demand more taxes to future generations. In this economic situation, the aging infrastructure could fail and cause more disasters due to the lack of budget for maintenance. There are 84,000 dams in the United States now, and approximately $32 \%$ of them, 27,000 dams have a possibility of damage or failure. 14,000 of them are classified as high hazard potential (FEMA, 2011).

On the other hand, the fundamental principle of landscape architecture is to create balance balance between the needs of people and the needs of the environment, between the manmade and the natural, between development and conservation. From this perspective, landscape architectural methods could provide different and alternative choices for flood management, and even bring more benefits to the communities.

\section{-Significance}

The field of landscape architecture, which started from gardening for enhancement of quality of life and beautification, has been expanding to designing parks, streetscapes, and communities with the demands from each period (ALSA, n.d.). Now, the role of landscape architecture is getting more and more important as a job dealing with natural environment which is fundamental for the safety and sustainability of human capital with the knowledge of ecology and new technology such as the environmental restoration techniques and stormwater management(ASLA, 2009). In fact, landscape architects are playing an important role in planning their nationallevel development planning with the climate change scenario to protect their land and human capital in Europe. In the United State, politics and engineering have been a great role in the field (Mener, 2007), but there are not many case studies addressing this issue from landscape 
architecture. This project will be one of the case studies proposing flood management with land planning and design from landscape architectural perspectives. It can propose a different ideology in the disaster management field, and also it will bring landscape architecture to a new frontier as a new profession.

\section{-Goals and objectives}

The goal of the project is to propose landscape planning and designs with flood management from a design simulation of the Bluestone Dam failure. To achieve this goal, the whole project is composed of two parts, one is in an upper stream community of the Bluestone Dam, and the other one is in a downstream community of the Bluestone Dam. The objective of the upper stream project is to mitigate the risk of a Bluestone dam failure by stormwater management planning. The objective of the downstream project is to propose planning and design to respond to manage flooding associated with a potential Bluestone Dam failure.

\section{Mitigate the risks of the hazard}

To mitigate the risks associated with a dam failure, the part in the upper stream community will focus on stormwater management planning to prevent the Bluestone Dam from failing. The main idea is to mitigate the risks of the dam failure by reducing the amount and the velocity of stormwater runoff discharging into the Bluestone Dam. It will be achieved by utilizing the techniques of Low Impact Development such as green roofs, raingardens, bioswales, bioretentions and so on. 


\section{Response to the hazard}

To respond to the hazard of the dam failure, the part of the project in the downstream community focuses on planning and design to respond the flood hazard by the Bluestone Dam failure. It is comprised of a city planning and a site design of the high damage risk area to reduce the risk of damages. The site design will also enhance the sustainability, economy and environment for the community.

\section{-Project Site and Methodology}

\section{Bluestone Dam}

Bluestone Dam is a concrete gravity dam located on the New River near Hinton, West Virginia. The Bluestone lake project was authorized in 1935 and completed in 1949 for the purpose of flood control and power development. The size of the reservoir is approximately 2,040 acres $\left(8.3 \mathrm{~km}^{2}\right)$ at the normal level, but the lake can expand over 36 miles $(58 \mathrm{~km})$ long at flood control pool, which extends into Giles County, Virginia. The drainage area is 4,565 sqmiles, which is the largest drainage area among all of the dams in West Virginia (Stowasser, 2011).

According to Lovely(2011), when the dam was planned in the late 1930s, it was designed to be able to impound the amount of runoff from the worst storm on record in the region, which was 13 inches of rain in 24 hours over the upper New River watershed by 1916 hurricane. However, standards for dam safety was changed due to the collapse and failure of other dams, and also the potential rainfall was increased to 20 inches, the U.S. Army Corps of Engineers concluded that the Bluestone dam does not meet the new safety standards. While there is room for some expansion for the water storage, a significantly higher elevation could threaten the 
structure's stability. Also, there is a concern about the dam's foundation. The Corps estimated the effects of disaster measured by the formula, probability of an event multiplied by consequences — both in terms of potential life lost and economic impact, and concluded that a failure of the Bluestone Dam would be catastrophic (Lovely, 2011). To remedy the problem of the dam safety, the Army Corps of Engineer has undertaken a Dam Safety Assurance program for Bluestone Dam which is composed of five-phase program. The estimated cost for the work is more than $\$ 250$ million, and the work include:

- $\quad$ Raising the dam 8 feet by installing a precast concrete wall;

- Stabilizing the dam with anchors and mass concrete thrust blocks;

- Improving the spillway; and

- Modifying six penstocks to increase discharge capacity, and installing scour protection for the penstocks.

Dam repair is a major method to prevent the dam from failing by the engineering perspective, but some other techniques and methods for managing stormwater could be applied from the landscape architectural perspective such as green infrastructure, zoning, planning and also designing spaces. It addresses the causes of the issue with the environmental aspects instead of the issue itself. Moreover, it can provide alternative choices and the cost performances could be better than that of the engineering method. In addition, landscape architecture enhances natural environment, revitalizes communities, and provides beauty and comfort to people's live as side benefits, which results in promoting sustainability in the region.

Mitigate the risks of the hazard - Upper stream Community: Blacksburg, VA 
To mitigate the risk of the Bluestone Dam failure, it is important to rethink how to manage the stormwater before it reaches to the dam. Reducing the amount of stormwater discharging into the dam will result in reducing the possibility of the dam failure. It is known that the amount of runoff from a storm is affected by land use (Sheaffer, Mullan \& Hinch, 2002). Communities, in the upper stream of the Bluestone Dam that have prospect of future growth, are expected to increase the stormwater impact to the Bluestone Dam in the future because of increasing amount of impervious surfaces. Blacksburg, an incorporated town located in Montgomery County, Virginia, located approximately 40 miles away from the Bluestone Dam, is one of the fastest growing town in Virginia, and it is selected as the case community for stormwater management for this project. As of the 2010 Census, the population of Blacksburg is 42,620(2010, census). Blacksburg is the largest town in Virginia by population, and it is in the $15^{\text {th }}$ largest municipality overall. Blacksburg is dominated economically and demographically by the presence of Virginia Polytechnic Institute and State University (better known as Virginia Tech), a Virginia land-grant university. The process of the project is as follows.

- PHASE1:General Inventory and Analysis

Understand the community by inventory \& analysis of the historic, environmental, social, and economic contexts

- PHASE2:Stormwater Analysis

Analyze the stormwater impacts in the future from the current land use and the future land use differences

- PHASE3:Planning 
Propose planning to mitigate the risk of the dam failure by stormwater management with green infrastructure. It will aim to "No net gain, or Less" with the Low-Impact Development strategy

\section{Response to the hazard - Downstream Community: Charleston}

For the part of the project in the downstream community, Charleston, the state capital of West Virginia as well as the county seat of Kanawha County, is selected, because it is one of the most important cities of West Virginia as the economic and political center of the state.

Charleston is located 60 miles downstream of the Bluestone Dam at the confluence of the Elk and Kanawha Rivers in Kanawha County. As of the 2010 Census, it had a population of 51,400, while its metropolitan area had 304,214. Population density is 1,630.7/sq. mi (629.6/km2). The area of the land is $31.52 \mathrm{sq} . \mathrm{mi}(81.64 \mathrm{~km} 2)$, and the area of water is $1.14 \mathrm{sq} . \mathrm{mi}(2.95 \mathrm{~km} 2)$. The elevation range is from 597 to 957 (varies due to mountains) $\mathrm{ft}$ (182 m), but most area of the city is on the elevation of $590 \mathrm{ft}$ to $700 \mathrm{ft}$. along the rivers. The water level is $570 \mathrm{ft}$, and there are only $20 \mathrm{ft}$. from the water level to the ground level where all the buildings and houses are standing. Because of the location where Charleston is established along the rivers, there are threats for flooding. According to the Charleston Evacuation Plan (Kanawha County, 2010) “Flood Insurance Rate Maps (FIRMs) created by FEMA, low-lying areas along the Kanawha, Elk, Pocatalico, and Coal River are in floodplains. Estimates provided by the Hazus program indicate that approximately 2,400 buildings would be at least moderately damaged by a 100 -year flood. Over 4,400 households could be displaced, necessitating an evacuation (albeit gradual) of as many as 8,500 people"(p.83). In their history, a flood struck Charleston and surrounding Kanawha valley on July-19-20, 1961 and it was the worst natural disasters ever to hit this area. 
Five adults and four children would die in what was then called Magazine Hollow, and 22 people overall died from the torrents of water. If the Bluestone dam fails, the damage could be more catastrophic. In this project, city planning will be proposed to minimize the potential damage and to respond efficiently when an emergency happens. The outline of the project is as follows.

- PHASE1:General Inventory and Analysis

Understand the upstream case communities through inventories \& analyses of the environmental, social, and economic contexts, and identify the community issues that could be improved through the disaster management plan and design.

- PHASE2:Flood Analysis

Recognize the high risk areas in the downstream community through analyses of floodplains, Bluestone Dam failure simulation, and also from the general inventory and analysis of the contexts

- PHASE3:Planning

Propose an upstream design guideline and downstream design plan for responding to the hazard of flood and Bluestone Dam failure

- PHASE4:Site Design

Propose a downstream site design at the high risk areas for responding to the hazard of flood and Bluestone dam failure, as well as enhancing the environment, economy, and sustainability of the city. 


\section{Summary, Conclusions and Recommendations}

\section{1) Summary}

\section{-Mitigate the risks of the hazard - Upper stream Community: Blacksburg, VA}

Blacksburg is the largest town in Virginia by population(42,620, 2010 census), and the 15 th largest municipality overall. It is one of the fastest growing areas in Virginia, and the stormwater impact will be increasing as a result of future development, which will increase the risk of the Bluestone Dam failure. This project was conducted with the following steps.

- PHASE1:General Inventory and Analysis

The historic context and the environmental contexts such as topography, hydrology, soil, and impervious surface area were analyzed as important elements to this project.

\section{- PHASE2:Stormwater Analysis}

The area of the land use change from the current land use to the future in 2046 was identified from GIS maps. Using the $\mathrm{Q} / \mathrm{i}$ from modified rational method formula $(\mathrm{Q}=\mathrm{CiA})$ as a parameter of stormwater amount, the amount of increasing stormwater in the future was calculated. The areas of low density residential use, medium density residential use, high density residential use, Commercial/Mixed Use/Professional Office use, Research/Light Industrial use, heavy industrial use, are expected to be increasing in the future. The total increase of the Q/I value from the current stormwater amount in the whole city is $10 \%$ in the future in 2046 by these land use changes. The goal of the planning is to propose a stormwater management guideline for new developments to achieve a goal of "No net gain, or Less" impact of stormwater with the LID(Low-Impact Development) strategy. 


\section{- PHASE3:Planning}

Three stormwater management scenarios were made through the process of a LID practice evaluation, a cost analysis, and a suitability analysis. In the LID practice evaluation, each major LID practice ( bioretentions, raingardens, greenroofs, bioswales, permeable pavers, infiltration trenches) were evaluated by the rate of stormwater reduction, installation cost, maintenance cost, life span, aesthetics, and also if it would enhance community engagement, and wildlife habitats. In the cost analysis, the cost performances were evaluated through the comparison of the cost of construction and annual maintenance of the LID practices, and that of the conventional stormwater management practices. In the suitability analysis, the suitability of LID practices for each land use was examined, and three scenarios are made to mitigate the stormwater increase in the future.

$\mathrm{Q} / \mathrm{i}$ value and the total cost per acre of each scenario were calculated. Scenario 3 can reduce the stormwater impact the most, 7\% less than the current land use, which means a total of $17 \%$ less than the prospective future land use. However, this scenario cost more than scenario 2. Scenario 2 will reduce the stormwater impact $3 \%$ from the current land use, and also save $\$ 1,213$ per acre for the future development. Scenario 4 was created from scenario $2 \& 3$ to aim to be in the middle of these two scenarios with better cost performance. The reason that scenario 3 cost more than scenario 2 is because of bioretentions. Although bioretentions are good in regards to aesthetics, community engagement, and wildlife habitats, the cost for the construction and maintenance is much more expensive than the other LID practices. Scenario 4 has the same LID practices as scenario 3 without bioretentions, and the result showed that Scenario 4 is the most feasible scenario among the four scenarios regarding to the suitability to each land use and cost performance. 
Scenario 4 will reduce the stormwater impact 5\% from the current land use, which means $15 \%$ from the prospective future land use. It will also save $\$ 1,159$ per acre for annual future development, which means $\$ 2,490,701$ in savings every year for the whole city. These savings could be spent on creating more bioretentions or the improvement of public services.

\section{-Response to the hazard - Downstream Community: Charleston}

- PHASE1:General Inventory and Analysis

The historic context, the environmental contexts, social contexts, economic contexts, and cultural contexts were analyzed as important elements to this project.

\section{- PHASE2:Flood Analysis}

The 10-100 year floodplains and the possible flood areas resulting from a Bluestone Dam failure were identified by GIS analysis. The areas covered with the100 years flood plain and higher than the 10 feet flood area by Bluestone Dam failure were recognized as the serious flood risk area. The possible damage from the floods was also estimated.

Using mapping the serious flood risk areas were overlaid with GIS maps of the total assets by census blocks, total assets per sq.mi., land use, population density, poverty rate to identify the high damage risk areas. The risk of economic and cultural loss, loss of life, and vulnerability of the land by the flood risk areas were taken into account for this process.

The high damage risk areas were identified from the overlaid maps. Three areas were identified with different visions and strategies for planning and design. Visions for the solutions were set for each area; One vision is a flexible waterfront design, which will attempt to create some flexible areas with temporary flooding to mitigate the damage from the floods as well as restore floodplain ecosystems. The second vision, the flood resistant 
design, will be assigned in the area that has buildings close to the river. The third vision, the planning for response, will focus on the safe areas outside of flood areas. These areas can provide safe shelters, temporary housings, and also emergency supplies such as energy, water, and food.

Strategies for each area were set; For the flexible waterfront design areas, the riverbank will be expanded with different levels by using stairs or terraces, and it will allow people to be close to the water, as well as create attractive spaces for different uses along the river. For the flood resistant design, floodwalls or some structure will be installed to protect the community from the flooding, and the structures will be designed not only as protective structures from flooding, but also as design elements to create attractive spaces to improve the city.

For the planning for response area, important facilities such as hospitals, possible shelters and temporary housing area will be identified in the safe area outside of flooding areas, in case if the floodwalls also failed.

- PHASE3:Planning

Taking the three strategies for each vision into account, the possible flood area, important elements for response such as shelters, hospitals, and parks for temporary housings, and also circulations, were overlaid, and a schematic master plan was made.

\section{- PHASE4:Site Design}

The downtown area of Charleston was identified as the highest damage risk area through the flood analysis. In this area, the site design was conducted to achieve the flood resistant and flexible design with the river dynamics as well as enhancement of sustainability of the 
city. Through the inventory and analysis on the site, areas for designing were identified along the river, where the city needs to improve by design to protect the city from the catastrophic flood by a Bluestone dam failure. The design concept was set as follows. "Charleston, which has a high damage risk from the possible Bluestone Dam failure, will be redesigned in harmony with the river dynamics(Chaos and Fractal) to be flexible and resistant against the flood risks. The city will become a bridge to the better future as well as a gateway to introduce a green economy and sustainable development into the region, which has relied on natural resources industries." To achieve the design concept, the following plans and designs were proposed.

1. Temporary floodwall structure as a gate park to the Kanawha river

To protect the city from the possible15'-20' flood by Bluestone Dam failure, 20 tall floodwall structures was proposed on the site. The floodwall structures would be opened and flexible as much as possible with the arch shaped windows, which would be closed temporarily during the flood emergency, and these structures create visual and physical connection to the river from the downtown area.

2. Flexible areas accepting natural flood events for floodplain ecosystem restoration

Through the flood analysis, high potential flood areas were identified for floodplain ecosystem restoration. These areas were designed to be acceptable areas for natural flood events such as 10 years to50 years flood events. It would restore the gradual ecotone along the river with floodplain plants communities and create habitats for wildlife. 
3. Kanawha Boulevard Road diet to create a better connection between the downtown area to the city

While the traffic is not so heavy on Kanawha Boulevard, it has 4 to 5 lanes now, and it is one of the big elements creating disconnection between the downtown area and the river. Reducing Kanawha Boulevard into two lanes will mitigate this disconnection as well as create more space for the open space along the river.

4. Multiple attractions for the community and mixed use development along the river

As the center of the city, the park was designed as the most active and attractive areas to bring people from the city as well as the outside of the city to the riverside. It will not only protect the city at the flooding emergency, but also enhance the city culturally and economically.

\section{2) Conclusions and Recommendations}

-Mitigate the risks of the hazard - Upper stream Community: Blacksburg, VA

The part of the project in Blacksburg, the upstream of the Bluestone Dam, could propose a practical stormwater management plan to mitigate the risk of the Dam failure. The guideline for stormwater management in Blacksburg will be able to reduce the impact of the future development to the environment and the risk of the Bluestone dam failure. This guideline also enable city to save the cost for the development of new infrastructure, as well as enhance 
aesthetics, community engagement, and wildlife habitats, which will improve the sustainability of the city. This project also proved that LID strategy is a practical tool for flood management in for the downstream community, and it is recommended to be applied to city planning more in the future.

\section{- Response to the hazard - Downstream Community: Charleston}

The part of the project in Charleston, the downstream of the Bluestone Dam, could propose an planning and design to be able to respond to a Bluestone dam failure. It suggested that the flood resistant riverfront design from landscape architectural view will bring various benefits to the community. It would not only protect the community from flooding, but also enhance the environment, culture, economic, and quality of life as a river friendly city. However the cost for the development, especially for the floodwall structure, will be one of the issues in this project, the cost would be less expensive than the total cost from the possible dam failure, and the benefits brought by the development will enhance the sustainability of the city. This project suggested the potential of landscape architecture that could play a great role to enhance the planning and designs in the field of disaster management, and it is recommended landscape architects to take part in the process of the disaster management more in the future. 


\section{References}

Arnold, J. USArmy Corps of Engineers, Fort Belvoir,Virginia, Office of History. (1988). The evolution of the 1936 flood control act. Retrieved from website: http://publications.usace.army.mil/publications/eng-pamphlets/EP_870-1-29/EP_870-129.pdf

ASLA(American Society of Landscape Architects). (2009, February 18). [Web log message]. Re-defining the Role of Landscape Architects.The Dirt. Retrieved from http://dirt.asla.org/2009/02/18/re-defining-the-role-of-landscape-architects/

ASLA(American Society of Landscape Architects).(n.d.). American Society of Landscape Architects. What is landscape Architecture. Retrieved July 10, 2013, from http://www.asla.org/design/index.html

FEMA( Federal Emergency Management Agency).(2011). Dam safety fact sheet. Retrieved from website: http://www.fema.gov/library/viewRecord.do?id=4136

IPCC(Intergovernmental Panel on Climate Change). (2007). Climate change 2007: Impacts, adaptation and vulnerability. summary for policy makers. Retrieved from website: http://www.ipcc.cg/SPM13apr07.pdf

Jha, A., Bloch, R., \& Lamond, J. GFDRR, (2011). Cities and flooding a guide to integrated urban flood risk management for the 21st century. Retrieved from website: http://reliefweb.int/sites/reliefweb.int/files/resources/Full_Report_3518.pdf 
Kanawha County. (2010). Kanawha county - city of charleston evacuation plan. Retrieved from website: http://www.kanawha.us/oem/documents/KanawhaCharlestonEvacuationPlan.pdf

Lovely,L. (2011, May 2). Army Corps Works to Avert Catastrophe. Construction Equipment Guide.com. Retrieved Feb 16, 2013, from http://www.constructionequipmentguide.com/Army-Corps-Works-to-AvertCatastrophe/15801/.

Mener, A. (2007). Disaster response in the united states of america: An analysis of the bureaucratic and political history of a failing system. Unpublished manuscript, College of Arts and Sciences, University of Pennsylvania, Philadelphia, , Available from ScholarlyCommons. Retrieved from http://repository.upenn.edu/cgi/viewcontent.cgi?article=1068\&context=curej

NWF(National Wildlife Federation). (2013). Changing course: why protecting floodplains is good for people and wildlife . Retrieved from website: https://www.nwf.org/News-andMagazines/Media-Center/Reports/Archive/2013/03-28-13-Changing-Course.aspx

Sheaffer, J. R., Mullan, J., \& Hinch, N. B. (2002). Encouraging Wise Use of FLOOD PLAINS with Market-Based Incentives. Environment, 44(1), 32.

UNISDR(United Nations Office for Disaster Risk Reduction). (Producer). (2012, 06 13). The impacts of disasters since the 1992 Earth Summit [Web Graphic]. Retrieved from http://www.flickr.com/photos/isdr/7368413022/

UNISDR. (2009). Briefing note 02: adaptation to climate change by reducing disaster risks. Retrieved from website: http://www.unisdr.org/we/inform/publications/11775 
U.S. ARMY. (n.d.). Flood Risk Management. In WWW.ARMY.MIL/ASACW . Retrieved July 16,2013, from http://asacw.hqda.pentagon.mil/floodmanagement.aspx.

WMO(World Meteorological Organization). (2004). Risk sharing in flood management. Retrieved from website: http://www.apfm.info/publications/tools/Tool_13_Risk_Sharing_in_FM.pdf 